\title{
Effect of High Hydrostatic Pressure on Ascorbic Acid, Phenolic Compounds and Antioxidant Activity of Pera Rio Orange Juice
}

\author{
Antonio Bisconsin-Junior ${ }^{1}$, José Fernando Rinaldi Alvarenga ${ }^{1}$, Amauri Rosenthal ${ }^{2}$ and Magali Monteiro ${ }^{1 *}$ \\ ${ }^{1}$ Department of Food and Nutrition, School of Pharmaceutical Sciences, São Paulo State University-UNESP, P.O. Box 502, 14801-902 Araraquara, SP, Brazil \\ ${ }^{2}$ Embrapa Food Technology, Av. das Américas, 29501, 23020-470 Rio de Janeiro, RJ, Brazil
}

\begin{abstract}
Orange juice is the most popular juice in the world, representing an important source of bioactive compounds in diet. High hydrostatic pressure (HHP) is an alternative technology that does not use high temperature, being able to preserve flavor and nutritional characteristics of the juice. The influence of HHP treatment conditions, pressure (100-600 MPa), temperature (30$60^{\circ} \mathrm{C}$ ) and time (30-360 s), on ascorbic acid, phenolic compounds and antioxidant activity of orange juice was investigated using response surface methodology. Analysis of variance showed that quadratic polynomial models fitted well with the experimental data for ascorbic acid $\left(R^{2}=0.92, p<0.01\right)$ and antioxidant activity using the $A B T S^{*}+$ assay $\left(R^{2}=0.91, p<0.01\right)$. The increase in time and temperature of HHP treatment promoted the reduction of ascorbic acid content and antioxidant activity in orange juice. HHP treatment reduced the ascorbic acid content and antioxidant activity of orange juice. The HHP treatment conditions of 100 to 250 $\mathrm{MPa}, 30$ to $40^{\circ} \mathrm{C}$ and 30 to $125 \mathrm{~s}$ were able to produce orange juice with more than $70 \%$ of the initial ascorbic acid content and $80 \%$ of the antioxidant activity.
\end{abstract}

Keywords: Antioxidant activity; Ascorbic acid; High hydrostatic pressure (HHP); Orange juice; Response surface methodology (RSM)

\section{Introduction}

Orange juice is the most consumed juice in the world, corresponding to $47 \%$ worldwide juice consumption [1]. It is an important source of bioactive compounds in diet, like flavonoids and carotenoids, as well as ascorbic acid. Ascorbic acid is considered the major antioxidant compound in orange juice, contributing with more than $90 \%$ of the antioxidant activity [2]. Orange juice flavanones, mainly hesperidin and narirutin, also present antioxidant activity [3-5], while carotenoids [6], mostly carotenes and cryptoxanthins, have provitamin A activity, and lutein and zeaxanthin, prevent macular degeneration [7]. Orange juice flavanones have been associated with reduced risk of coronary heart disease [8-10]. Ascorbic acid also contributes to the maintenance of the vascular health and to reduce atherogenesis, regulating the collagen synthesis, prostacyclin production, and nitric oxide [11,12]. Some studies indicated that orange juice consumption may reduce Low Density Lipoprotein Cholesterol (LDL) and improve high density lipoprotein (HDL) cholesterol in hypercholesterolemic subjects, as well as reduce oxidative stress (8-epi-PGF ${ }_{2 \alpha}$ ) and uric acid in plasma [13].

The most extensively process used for orange juice is thermal pasteurization, which inactivates vegetative microorganisms and enzymes. But, pasteurization at intense time/temperature conditions induces to ascorbic acid and natural flavor losses, as well as carotenoids and color changes, so affecting the juice's overall quality [14-17].

Due to consumers demand the fruit juice industry has been exploring innovative technologies, which requires minimal heat treatment, able to produce juice with fresh-like and natural-like attributes, to preserve flavor and nutritional aspects [18]. High Hydrostatic Pressure (HHP) reduces orange juice spoilage microflora $[19,20]$ and PME activity [2123] without using high temperature, therefore reserving sensory and nutritional characteristics. Color, flavor, soluble solids, $\mathrm{pH}$ and other compounds of orange juice are not considerably affected. Orange juice spoilage microflora was studied after $\mathrm{HHP}$ at $360 \mathrm{MPa}, 35^{\circ} \mathrm{C}$ for 2 min with a $7 \log$ cycle reduction of Lactobacillus plantarum and $L$. brevis. HHP treatment of orange juice at $600 \mathrm{MPa}$ during $60 \mathrm{~s}$ reduced aerobic microorganisms, and yeasts and molds counts to not detectable levels $(<10 \mathrm{CFU} / \mathrm{mL})$ for juice from Valencia and Navel varieties and $400 \mathrm{MPa}$ for $90 \mathrm{~s}$ for juice from Hamlin HHP of Navel orange juice at $600 \mathrm{MPa}, 20^{\circ} \mathrm{C}$ for $60 \mathrm{~s}$ exhibited a $45 \%$ reduction in PME activity, while the same treatment conditions were enough to inactivate $92 \%$ of PME orange juice derived from a mixture of three orange varieties. Bisconsin-Junior reported the range of 550 to $600 \mathrm{MPa}, 55$ to $60^{\circ} \mathrm{C}$ and 330 to $360 \mathrm{~s}$ to produce orange juice with PME residual activity of less than $20 \%$ and low microorganism count. PME inactivation depends on the enzyme environment of the particular food system and even on the variety and origin of orange juice.

There are many studies about the influence of some HHP treatments on ascorbic acid and/or antioxidant activity of orange juice [24-28], however the effects of a range of treatment conditions were not determined yet. So, there is no information regarding ascorbic acid and antioxidant activity of orange juice under multiple and simultaneous conditions of HHP.

Bull reported that Valencia orange juice treated at $600 \mathrm{MPa}, 20^{\circ} \mathrm{C}$ for $60 \mathrm{~s}$ did not had ascorbic acid significantly affected, however Sanchez-Moreno $\mathrm{C}$ found $11 \%$ reduction in ascorbic acid of the juice treated at $100 \mathrm{MPa}, 60^{\circ} \mathrm{C}$ during $300 \mathrm{~s}$. Ancos studied the effect of HHP on carotenoids and antioxidant activity of Valencia orange juice. The highest amount of vitamin $\mathrm{A}$ and extractable carotenoids in orange juice was obtained at $350 \mathrm{MPa}, 30^{\circ} \mathrm{C}$ for $300 \mathrm{~s}$, although there was a reduction of $22 \%$ on antioxidant activity. Sanchéz-Moreno

*Corresonding author: Magali Monteiro, Department of Food and Nutrition School of Pharmaceutical Science, São Paulo State University-UNESP, Rodovia Araraquara - Jaú Km 1, P.O. Box 502, 14801-902 Araraquara, SP, Brazil, Tel: +55 163301 6930; E-mail: monteiro@fcfar.unesp.br

Received November 26, 2014; Accepted January 08, 2014; Published January 15,2015

Citation: Bisconsin-Junior A, Alvarenga JFR, Rosenthal A, Monteiro M (2015) Effect of High Hydrostatic Pressure on Ascorbic Acid, Phenolic Compounds and Antioxidant Activity of Pera Rio Orange Juice. J Food Process Technol 6: 416 doi:10.4172/2157-7110.1000416

Copyright: (C) 2015 Bisconsin-Junior A, et al. This is an open-access article distributed under the terms of the Creative Commons Attribution License, which permits unrestricted use, distribution, and reproduction in any medium, provided the original author and source are credited. 
Citation: Bisconsin-Junior A, Alvarenga JFR, Rosenthal A, Monteiro M (2015) Effect of High Hydrostatic Pressure on Ascorbic Acid, Phenolic Compounds and Antioxidant Activity of Pera Rio Orange Juice. J Food Process Technol 6: 416. doi:10.4172/2157-7110.1000416

Page 2 of 7

reported that after $400 \mathrm{MPa}, 40^{\circ} \mathrm{C}$ for $60 \mathrm{~s}$ orange juice showed no significant reduction on vitamin $\mathrm{C}$, but presented higher extractability of carotenoids (54\%) and flavonones (34\%), however there was no significant difference on antioxidant activity.

The novelty of this work is to evaluate the influence of HHP treatment conditions (pressure, temperature and time) on ascorbic acid, phenolic compounds and antioxidant activity of Pêra Rio orange juice using response surface methodology.

\section{Material and Methods}

\section{Chemicals}

ABTS: 2,2'-azino-bis(3-ethylbenzothiazoline-6-sulfonic acid) diammonium salt, Trolox: 6-hydroxy-2,5,7,8-tetramethylchroman2-carboxylic acid, DPPH: 2,2-diphenyl-1-picrylhydrazyl, sodium carbonate, and gallic acid were from Sigma-Aldrich (St Louis, MO, USA); ascorbic acid and glucose from Merck (Darmstadt, Alemanha); Folin-Ciocalteu reagent from Imbralab (Ribeirão Preto, SP, Brazil); potassium persulfate from Fluka (Steinheim, Germany); methanol from JT Baker (Philipsburg, PA, USA), sodium hydroxyl, potassium sodium tartrate tetrahydrate, cupric sulfate pentahydrate and potassium phosphate dibasic from Labsynth (Diadema, SP, Brazil); oxalic acid and 2,6-dichloroindophenol sodium salt hydrate from Vetec (Rio de Janeiro, RJ, Brazil).

\section{Orange juice}

The fruits were from Pêra Rio variety, supplied by a citrus industry from Araraquara, SP. Fruits were cultivated in Bauru, SP, Brazil $\left(22^{\circ} 25^{\prime}\right.$ $59^{\prime \prime}$; $\left.49^{\circ} 10^{\prime} 31^{\prime \prime} \mathrm{W}\right)$, during the 2011/2012 harvest. The extraction of orange juice was performed in a JBT 391B extractor using the premium juice extractor settings and a UFC-35 finisher $(0.25 \mathrm{~mm}$ sieve $)$ at the JBT FoodTech Citrus System, Araraquara, SP, Brazil. After extraction, the juice was frozen and storage at $-18^{\circ} \mathrm{C}$.

\section{Physicochemical evaluation of non-treatment orange juice}

Total soluble solids, titratable acidity, $\mathrm{pH}$, ascorbic acid, total e reducing sugars of non-treatment orange juices were determined according to AOAC [29]. Ratio, the total soluble solids/titratable acidity rate, was calculated.

\section{High hydrostatic pressure (HHP) treatment}

For the HHP treatment, orange juice $(100 \mathrm{~mL})$ was packaged in heat sealed PE bags (Selovac 200B II, Selovac, São Paulo, Brazil), excluding as much air as possible. Orange juice was pressurized, according to the experimental design, in a Stansted Food Lab 9000 (Stansted Fluid Power, Stansted, UK) within a pressure vessel of $500 \mathrm{~mL}$. The maximum nominal operation pressure is $900 \mathrm{MPa}$ and temperature range -20 to $90^{\circ} \mathrm{C}$. The vessel temperature was controlled by water circulation in the outer jacket connected to a heating-cooling system. The pressure transmitting fluid was an ethanol:water solution (70:30, v/v). The compression rate was $7 \mathrm{MPa}^{-1} \mathrm{~s}^{-1}$ and decompression time less than $10 \mathrm{~s}$. Compression and decompression times were not included in the experimental design.

Prior to HHP treatment, the adiabatic heating of orange juice and pressurizing fluid of each experimental condition were evaluated. The adiabatic heating ranged from 2.8 to $3.5^{\circ} \mathrm{C}$ per $100 \mathrm{MPa}$ for orange juice and from 3.6 to $6.8^{\circ} \mathrm{C}$ per $100 \mathrm{MPa}$ for the pressurizing fluid. Temperature of orange juice bags and vessel was adjusted to a few degrees below the temperature of each experimental condition in order to achieve the temperature according to the central composite rotatable design (CCRD) during pressurization.

Non treated orange juice was used for comparison with the HHP treated orange juice.

\section{Experimental design}

The effect of HHP treatment conditions (independent variables), namely pressure, temperature and time, on total phenolic compounds, ascorbic acid and antioxidant activity (response variables) of HHP treated orange juice, were evaluated using the response surface methodology.

A CCRD of three independent variables with five levels, containing a $2^{3}$ factorial design, 6 axials points and 3 repetitions of the central point, totalizing 17 essays was used. The levels of the independent variables were coded as: -1 and +1 , representing the levels of $2^{3}$ factorial design; 0 (zero), representing the central point of the design, used to calculate the lack of fit and the pure error of the statistical model; -1.68 and +1.68 , representing the axial points, allowing a quadratic statistical model (Table 1). Data from the CCRD were analyzed by multiple regressions to fit the following quadratic polynomial model: (Equation 1)

$$
\mathrm{Y}=\beta_{0}+\beta_{1} P+\beta_{2} T+\beta_{3} t+\beta_{11} P^{2}+\beta_{22} T^{2}+\beta_{33} t^{2}+\beta_{12} P T+\beta_{13} P t+\beta_{23} T t
$$

where $Y=$ predicted response variable, $\beta_{0}=$ constant, $\beta_{1}, \beta_{2}$, and $\beta_{3}=$ linear coefficients, $\beta_{11}, \beta_{22}$, and $\beta_{33}$ =quadratic coefficients, $\beta_{12}, \beta_{13}$, and $\beta_{23}$ =interactive coefficients. The independent variables are $P=$ pressure, $T=$ temperature and $t=$ time. The non significant terms were taken out from the quadratic polynomial model after the ANOVA. A new ANOVA only containing the significant terms was performed to obtain the regression coefficients of the final equation in order to improve accuracy.

\section{Ascorbic acid}

Ascorbic acid of the HHP orange juice was based on the reduction of 2,6-dichloroindophenol. Triplicate analyses were performed and results were expressed as $\mathrm{mg}$ of ascorbic acid $\mathrm{L}^{-1}$ of orange juice [30].

\section{Extraction of antioxidant compounds}

The extraction of antioxidant compounds of the HHP orange juice was based on the procedure reported by Stella SP [31]. Orange juice $(5 \mathrm{~mL})$ and a methanol: water solution $(80: 20$, v/v) $(10 \mathrm{~mL})$ were vortexed for $1 \mathrm{~min}$ and then submitted to an ultrasonic bath at room temperature for $15 \mathrm{~min}$. The mixture was centrifuged at $21000 \mathrm{~g}$ for 20 $\min$ at $20^{\circ} \mathrm{C}$ and the supernatant collected. The extraction procedure was repeated once using the same conditions.

Total phenolic compounds: The total phenolic compounds of the HHP orange juice were determined using the Folin-Ciocalteu assay as reported by Asami [32] with minor modifications. In a $5 \mathrm{~mL}$ volumetric flask, $1 \mathrm{~mL}$ of water, $0.2 \mathrm{~mL}$ of extract and $0.06 \mathrm{~mL}$ of Folin-Ciocalteu reagent were added, mixed and allowed to stand at room temperature for $8 \mathrm{~min}$. After that, $2 \mathrm{~mL}$ of a sodium carbonate solution $(7 \%, \mathrm{w} / \mathrm{v})$ was added and then the flask volume was adjusted with distilled water, mixed, and heated at $40^{\circ} \mathrm{C}$ for $30 \mathrm{~min}$ in a water bath. The absorbance

\begin{tabular}{|l|l|l|l|l|l|}
\hline \multirow{2}{*}{ Independent variables } & \multicolumn{4}{l}{ Values of levels } \\
\cline { 2 - 6 } & -1.68 & -1 & 0 & +1 & +1.68 \\
\hline Pressure (MPa) & 100 & 201 & 350 & 499 & 600 \\
\hline Temperature $\left({ }^{\circ} \mathrm{C}\right)$ & 30 & 36 & 45 & 54 & 60 \\
\hline Time (s) & 30 & 97 & 195 & 293 & 360 \\
\hline
\end{tabular}

Table 1: Levels and corresponding values of the independent variables. 
Citation: Bisconsin-Junior A, Alvarenga JFR, Rosenthal A, Monteiro M (2015) Effect of High Hydrostatic Pressure on Ascorbic Acid, Phenolic Compounds and Antioxidant Activity of Pera Rio Orange Juice. J Food Process Technol 6: 416. doi:10.4172/2157-7110.1000416

Page 3 of 7

was measured at $740 \mathrm{~nm}$ using a spectrophotometer (Evolution 220, Thermo Scientific, USA). Quantification was carried out using a gallic acid calibration curve ( 50 to $220 \mu \mathrm{g} / \mathrm{mL}$ ) and the results were expressed as miligrams of gallic acid. $\mathrm{L}^{-1}$ of orange juice. Triplicate analyses were performed.

Antioxidant activity with DPPH' assay: The DPPH' assay was based on the method described by Rufino MSM [33] with some modifications. A methanol solution containing $0,06 \mathrm{mM} \mathrm{DPPH}^{*}$ was prepared. A $100 \mu \mathrm{L}$ aliquot of the whole extract of antioxidant compounds and 1:1 and 4:5 methanol:water $(80: 20 \mathrm{v} / \mathrm{v})$ solutions of the extracts was mixed with $3 \mathrm{~mL} \mathrm{DPPH}^{\bullet}$ radical solution. Absorbance readings at $515 \mathrm{~nm}$ in a spectrophotometer (Evolution 220, Thermo Scientific, USA) were done after $30 \mathrm{~min}$ of reaction. Trolox ethanolic solutions $\left(100-500 \mu \mathrm{mol} \mathrm{L}^{-1}\right)$ were used for calibration curves. The analyses were performed in triplicate and results expressed as $\mu \mathrm{mol}$ Trolox $\mathrm{L}^{-1}$ of orange juice.

Antioxidant activity with $\mathrm{ABTS}^{*+}$ assay: The $\mathrm{ABTS}^{\cdot+}$ assay was based on the method described by Rufino MSM. The ABTS radical cation $\left(\mathrm{ABTS}^{+}\right)$was obtained from the reaction between $5.0 \mathrm{~mL}$ ABTS $\left(7 \mathrm{mmol} \mathrm{L}^{-1}\right)$ with $88 \mu \mathrm{L}$ potassium persulfate $\left(140 \mathrm{mmol} \mathrm{L}^{-1}\right)$. The solution was allowed to stand in the dark for $16 \mathrm{~h}$ to ensure the complete formation of stable ABTS radical. The ABTS radical solution was diluted with ethanol to an absorbance of $0.70 \pm 0.05$ at $734 \mathrm{~nm}$. A $30 \mu \mathrm{L}$ aliquot of the whole extract of antioxidant compounds and 1:1 and 4:5 methanol:water $(80: 20 \mathrm{v} / \mathrm{v})$ solutions of the extracts was mixed with $3 \mathrm{~mL}$ ABTS radical solution. Absorbance readings at $734 \mathrm{~nm}$ were done after $6 \mathrm{~min}$ of reaction in a spectrophotometer (Evolution 220, Thermo Scientific, USA). Trolox ethanolic solutions (100-1200 $\mu \mathrm{mol}$ $\mathrm{L}^{-1}$ ) were used for calibration curves. The analyses were performed in triplicate and results expressed as $\mu \mathrm{mol}$ Trolox $\mathrm{L}^{-1}$ of orange juice.

\section{Data analyses}

Results were expressed as mean \pm standard deviation of three replicated analyses. ANOVA of the regression equations allowed to verify the adequacy of the model by evaluating the $F$ test value, the lack of fit, the coefficient of determination $\left(R^{2}\right)$, and significance of the effects using Statistica software version 10.0 (StatSoft, Tulsa, USA).

\section{Results and Discussion}

\section{Physicochemical evaluation of the non-treated orange juice}

Total soluble solids was $9.03 \pm 0.00{ }^{\circ}$ Brix, titratable acidity 5.78 $\pm 0.03 \mathrm{~g}$ of citric acid. $\mathrm{L}^{-1}, \mathrm{pH} 4.18 \pm 0.01$, and reducing and total sugar were $33.04 \pm 0.26$ and $62,62 \pm 0.47 \mathrm{~g}$ of glucose. $\mathrm{L}^{-1}$, respectively. Ascorbic acid was $859.5 \pm 11.4 \mathrm{mg} . \mathrm{L}^{-1}$ and ratio (soluble solids/titratable acidity) was 15.57 . The physicochemical characteristics were in accordance with the Brazilian law, except for total soluble solids content [34].

\section{Effect of HHP treatment conditions on ascorbic acid}

Table 2 shows the ascorbic acid content from the non-treated and HHP treated orange juice under each experimental condition. The non-treated orange juice presented higher ascorbic acid content (859.52 mg L-1) when compared to the Brazilian (82 to $570 \mathrm{mg} \mathrm{L}^{-1}$ ) and to the Spanish (196 to $634 \mathrm{mg} \mathrm{L}^{-1}$ ) [35] commercial orange juice. The HHP treated orange juice showed ascorbic acid ranging from 435.9 to $710.2 \mathrm{mg} \mathrm{L}^{-1}$. The experimental condition that most affected ascorbic acid $\left(435.9 \mathrm{mg} \mathrm{L}^{-1}\right)$ was $350 \mathrm{MPa}, 45^{\circ} \mathrm{C}$ and $360 \mathrm{~s}$, which degradation was more than $50 \%$, mainly related to the longest time of process. High ascorbic acid levels are used as quality index of fruits and juices, because ascorbic acid is more sensitive to degradation during process than other bioactive compounds associated to health benefits [36]. The ascorbic acid degradation was higher than that observed in some studies. Orange juice from Valencia and Navel treated at 400 $\mathrm{MPa}, 40^{\circ} \mathrm{C}$ during $60 \mathrm{~s}$ had $5 \%$ and $8 \%$ of ascorbic acid degradation, respectively. Sánchez-Moreno $\mathrm{C}$ obtained similar results as ours where higher ascorbic acid reduction (11\%) resulted from longer time and higher temperature $\left(100 \mathrm{MPa}, 60^{\circ} \mathrm{C}, 300 \mathrm{~s}\right)$, when compared to the orange juice treated at $400 \mathrm{MPa}, 40^{\circ} \mathrm{C}$ for $60 \mathrm{~s}$, which ascorbic acid reduction was $7 \%$.

The ascorbic acid content of orange juice submitted to different conditions of pressure, temperature and time along the 17 experiments according to the CCRD was statistically analyzed. The quadratic model for ascorbic acid was significantly fit to the experimental data, as indicated by the regression model $F$ value of $8.80(\mathrm{p}<0.01)$, and presented a satisfactory determination coefficient $\left(\mathrm{R}^{2}=0.92\right)$. No

\begin{tabular}{|c|c|c|c|c|c|c|c|}
\hline \multirow[t]{2}{*}{ Experiment } & \multirow{2}{*}{$\begin{array}{c}\text { Pressure } \\
\text { (MPa) }\end{array}$} & \multirow{2}{*}{$\begin{array}{c}\text { Temperature } \\
\left({ }^{\circ} \mathrm{C}\right)\end{array}$} & \multirow{2}{*}{$\begin{array}{c}\text { Time } \\
\text { (s) }\end{array}$} & \multirow{2}{*}{$\begin{array}{l}\text { Ascorbic acid } \\
\left(\mathrm{mg} \mathrm{L}^{-1}\right)\end{array}$} & \multirow{2}{*}{$\begin{array}{l}\text { Total phenolic } \\
\text { compounds } \\
\text { (mg Galic acid. } L^{-1} \text { ) }\end{array}$} & \multicolumn{2}{|c|}{$\begin{array}{c}\text { Total antioxidant activity } \\
\left(\mu \mathrm{mol} \text { Trolox. } \mathrm{L}^{-1}\right)\end{array}$} \\
\hline & & & & & & DPPH & ABTS \\
\hline Non treated & - & - & - & $859.5 \pm 11.4$ & $416.7 \pm 16.7$ & $2211.7 \pm 59.8$ & $3176.7 \pm 103.8$ \\
\hline 1 & 201 & 36 & 97 & $710.2 \pm 4.3$ & $426.4 \pm 28.5$ & $2169.4 \pm 33.8$ & $2708.6 . \pm 128.3$ \\
\hline 2 & 499 & 36 & 97 & $640.1 \pm 4.3$ & $447.7 \pm 21.1$ & $2182.0 \pm 27.2$ & $2737.6 \pm 100.3$ \\
\hline 3 & 201 & 54 & 97 & $618.7 \pm 4.3$ & $421.7 \pm 20.4$ & $2021.4 \pm 44.3$ & $2563.8 \pm 55.7$ \\
\hline 4 & 499 & 54 & 97 & $582.2 \pm 4.3$ & $434.7 \pm 2.3$ & $1991.7 \pm 60.8$ & $2550.4 \pm 136.3$ \\
\hline 5 & 201 & 36 & 293 & $539.5 \pm 11.4$ & $427.7 \pm 14.1$ & $2048.6 \pm 41.7$ & $2621.5 \pm 86.4$ \\
\hline 6 & 499 & 36 & 293 & $512.1 \pm 18.8$ & $419.6 \pm 5.5$ & $2039.5 \pm 11.0$ & $2353.7 \pm 133.2$ \\
\hline 7 & 201 & 54 & 293 & $445.0 \pm 4.3$ & $402.1 \pm 5.1$ & $2015.5 \pm 92.8$ & $2266.8 \pm 146.4$ \\
\hline 8 & 499 & 54 & 293 & $457.2 \pm 11.4$ & $401.7 \pm 6.8$ & $1823.1 \pm 14.5$ & $2062.0 \pm 114.2$ \\
\hline 9 & 100 & 45 & 195 & $557.8 \pm 11.4$ & $386.0 \pm 12.2$ & $1876.9 \pm 40.4$ & $2416.1 \pm 35.8$ \\
\hline 10 & 600 & 45 & 195 & $521.2 \pm 4.3$ & $404.8 \pm 7.8$ & $1864.3 \pm 33.9$ & $2304.8 \pm 11.2$ \\
\hline 11 & 350 & 30 & 195 & $536.4 \pm 11.4$ & $406.8 \pm 10.2$ & $1761.1 \pm 26.7$ & $2351.1 \pm 77.6$ \\
\hline 12 & 350 & 60 & 195 & $499.9 \pm 4.3$ & $418.3 \pm 2.7$ & $1811.1 \pm 34.9$ & $2120.4 \pm 64.9$ \\
\hline 13 & 350 & 45 & 30 & $621.8 \pm 4.3$ & $425.5 \pm 9.2$ & $1759.0 \pm 42.8$ & $2935.9 \pm 146.6$ \\
\hline 14 & 350 & 45 & 360 & $435.9 \pm 4.3$ & $404.8 \pm 17.5$ & $1751.1 \pm 11.8$ & $2112.2 \pm 57.6$ \\
\hline 15 & 350 & 45 & 195 & $509.0 \pm 8.6$ & $421.6 \pm 4.3$ & $1745.3 \pm 15.3$ & $2402.8 \pm 59.9$ \\
\hline 16 & 350 & 45 & 195 & $496.8 \pm 7.5$ & $428.8 \pm 7.8$ & $1766.0 \pm 23.4$ & $2469.6 \pm 114.8$ \\
\hline 17 & 350 & 45 & 195 & $518.2 \pm 4.3$ & $424.6 \pm 10.4$ & $1747.8 \pm 13.2$ & $2484.0 \pm 94.8$ \\
\hline
\end{tabular}

Table 2: The central composite rotatable design (CCRD) and experimental response values for HHP treated orange juice. 
Citation: Bisconsin-Junior A, Alvarenga JFR, Rosenthal A, Monteiro M (2015) Effect of High Hydrostatic Pressure on Ascorbic Acid, Phenolic Compounds and Antioxidant Activity of Pera Rio Orange Juice. J Food Process Technol 6: 416. doi:10.4172/2157-7110.1000416

\begin{tabular}{|c|c|c|c|c|}
\hline \multirow{2}{*}{ Source of variation ${ }^{1}$} & \multirow{2}{*}{ Ascorbic acid } & \multirow{2}{*}{$\begin{array}{c}\text { Total phenolic } \\
\text { compounds }\end{array}$} & \multicolumn{2}{|c|}{ Antioxidant activity } \\
\hline & & & DPPH & ABTS \\
\hline Regression model & $8.80^{\mathrm{b}}$ & $1.87^{\text {ns }}$ & $1.08^{\mathrm{ns}}$ & $7.20^{\mathrm{b}}$ \\
\hline$P$ & $21.50^{c}$ & $18.38^{\circ}$ & $33.12^{\mathrm{c}}$ & $16.19^{d}$ \\
\hline$T$ & $83.25^{c}$ & $54.18^{c}$ & $147.19^{b}$ & $72.98^{b}$ \\
\hline$t$ & $529.04^{b}$ & $14.17^{c}$ & $116.60^{\mathrm{b}}$ & $272.24^{c}$ \\
\hline$P^{2}$ & $33.80^{\mathrm{c}}$ & ns & $763.88^{b}$ & $0.25^{\mathrm{ns}}$ \\
\hline$T^{2}$ & $12.10^{\mathrm{b}}$ & $18.08^{\circ}$ & $359.49^{b}$ & $15.30^{d}$ \\
\hline$t^{2}$ & $21.24^{c}$ & $23.43^{\text {ns }}$ & $235.81^{\mathrm{b}}$ & $15.79^{b}$ \\
\hline$P T$ & $5.84^{\mathrm{ns}}$ & ns & $49.86^{c}$ & $0.03^{\text {ns }}$ \\
\hline$P t$ & $9.12^{\mathrm{d}}$ & $17.30^{\circ}$ & $36.39^{c}$ & $15.87^{d}$ \\
\hline$T t$ & ns & ns & ns & $6.58^{\mathrm{ns}}$ \\
\hline Lack of fit & $12.23^{\text {ns }}$ & $15.95^{\text {ns }}$ & $268.74^{\text {ns }}$ & $8.57^{\mathrm{ns}}$ \\
\hline $\mathbf{R}^{2}$ & 0.9164 & 0.51223 & 0.4462 & 0.9052 \\
\hline
\end{tabular}

${ }^{1} P=$ pressure. $T$ =temperature. $t=$ time.

${ }^{a} p \leq 0.01 .{ }^{b} p \leq 0.05 .{ }^{c} p \leq 0.10$

${ }^{\mathrm{n} N}$ Non-significant.

Table 3: ANOVA ( $F$ value) of the quadratic model for ascorbic acid content. total phenolic compounds and antioxidant activity of the HHP treated orange juice.

\begin{tabular}{|c|c|c|}
\hline Source of variation $^{\mathbf{1}}$ & Ascorbic acid content & Antioxidant activity (ABTS) \\
\hline Mean/Interception & 1297.481 & 2127.168 \\
\hline $\boldsymbol{P}$ & -0.829 & 0.498 \\
\hline $\boldsymbol{T}$ & -15.442 & 43.555 \\
\hline $\boldsymbol{t}$ & -1.548 & -2.662 \\
\hline $\boldsymbol{P}^{\mathbf{2}}$ & $\left(8.371 \times 10^{-4}\right)$ & - \\
\hline $\boldsymbol{T}^{\mathbf{2}}$ & 0.139 & -0.608 \\
\hline $\boldsymbol{t}^{\mathbf{2}}$ & $\left(1.525 \times 10^{-3}\right)$ & $\left(5.518 \times 10^{-3}\right)$ \\
\hline $\boldsymbol{P t}$ & $\left(7.829 \times 10^{-4}\right)$ & $-\left(4.180 \times 10^{-3}\right)$ \\
\hline
\end{tabular}

${ }^{1} P=$ pressure. $T=$ temperature. $t=$ time.

Table 4: Significant regression coefficients of the quadratic model for ascorbic acid content and antioxidant activity of HHP treated orange juice.

significant lack of fit of the model was found ( $p>0.05$ ), showing that it fits properly for prediction within the range of the studied HHP treatment conditions. Terms with significant $F$ value $(\mathrm{p} \leq 0.1)$ were included in the model. The linear and quadratic terms of pressure $(P$, $\left.P^{2}\right)$, temperature $\left(T, T^{2}\right)$ and time $\left(t, t^{2}\right)$, as well as the interaction term of pressure and time $(P t)$ were significant (Table 3 ). These statistical parameters confirm the consistency of the model, indicating it is reliable to predict ascorbic acid content in HHP treated orange juice. Using the significant regression coefficients (Table 4) the following model equation for ascorbic acid content was generated: (Equation 2)

Ascorbic Acid $=1297.481-0.829 \mathrm{P}-15.442 \mathrm{~T}-1.548 \mathrm{t}+(8.371 \mathrm{x}$ $\left.10^{-4}\right) \mathrm{P}^{2}+0.139 \mathrm{~T}^{2}+\left(1.525 \times 10^{-3}\right) \mathrm{t}^{2}+\left(7.829 \times 10^{-4}\right) \mathrm{Pt}$

where, Ascorbic Acid=ascorbic acid content $\left(\mathrm{mg} \mathrm{L}^{-1}\right), \mathrm{P}=$ pressure $(\mathrm{MPa}), \mathrm{T}=$ temperature $\left({ }^{\circ} \mathrm{C}\right)$ and $\mathrm{t}=$ time $(\mathrm{s})$.

The response surface was generated from the regression equation (Eq. 2) to illustrate the effects of the independent variables on the ascorbic acid content (Figure 1). One of the variables was kept at the central point of the design (zero level) while the other two variables were changed within the experimental range. An increase in temperature and time promoted the reduction of the ascorbic acid content in HHP treated orange juice. The independent variable of time was the most important one affecting ascorbic acid reduction in HHP treated orange juice (Figure $1 \mathrm{a}$ and $1 \mathrm{~b}$ ). As it can be seen in Figure $1 \mathrm{~b}$ and $1 \mathrm{c}$, from 100 to $300 \mathrm{MPa}$ ascorbic acid was reduced, but from 500 to $600 \mathrm{MPa}$ a slight increase on ascorbic acid was observed. The increase in ascorbic acid
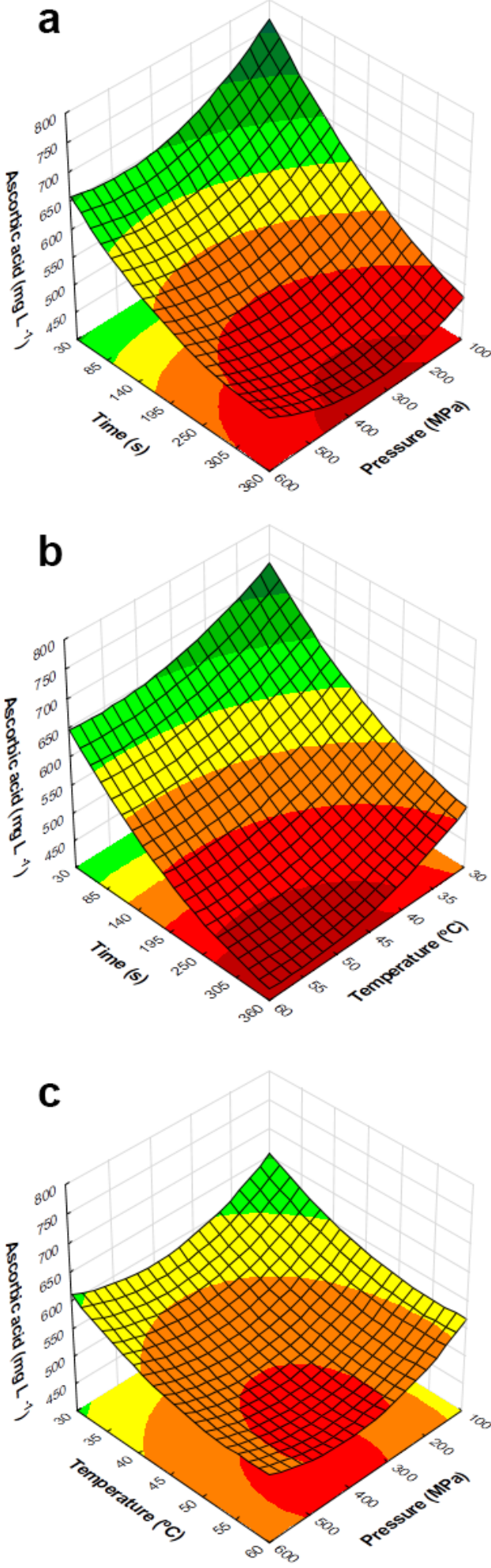

Figure 1: Response surface of the combined effects of time and pressure (a) time and temperature (b), and temperature and pressure (c) on the ascorbic acid content of HHP processed orange juice. 
Citation: Bisconsin-Junior A, Alvarenga JFR, Rosenthal A, Monteiro M (2015) Effect of High Hydrostatic Pressure on Ascorbic Acid, Phenolic Compounds and Antioxidant Activity of Pera Rio Orange Juice. J Food Process Technol 6: 416. doi:10.4172/2157-7110.1000416

Page 5 of 7

can be resulted from eliminating part of enzyme-catalyzed oxidation (ascorbate oxidase and peroxidase), responsible for vitamin C loss.

According to the model equation (Eq. 2), in order to obtain ascorbic acid content higher than $600 \mathrm{mg} \mathrm{L}^{-1}$, representing $70 \%$ of the initial orange juice ascorbic acid content, the range of 100-250 $\mathrm{MPa}$, $30-40^{\circ} \mathrm{C}$ and $30-125 \mathrm{~s}$ HHP treatment conditions should be used.

\section{Effect of HPP treatment conditions on total phenolic compounds}

Total phenolic compounds of non-treated orange juice was 416.7 $\mathrm{mg}$ acid galic. $\mathrm{L}^{-1}$ and for the processed orange juice using HHP, according to the CCRD with 17 experiments, ranged from 386,0 to 447,7 $\mathrm{mg}$ acid galic. $\mathrm{L}^{-1}$. The highest content of total phenolic compounds was obtained at $499 \mathrm{MPa}, 36^{\circ} \mathrm{C}$ and $97 \mathrm{~s}$, while at $100 \mathrm{MPa}, 45^{\circ} \mathrm{C}$ and $195 \mathrm{~s}$ was the lowest content (Table 2). Sánchez-Moreno C showed that HHP orange juice processed at $400 \mathrm{MPa}, 40^{\circ} \mathrm{C}$ and $60 \mathrm{~s} \mathrm{had} \mathrm{higher} \mathrm{content} \mathrm{of}$ total flavanones $\left(18.70 \mathrm{mg} .100 \mathrm{~mL}^{-1}\right)$, narigenin $\left(4.47 \mathrm{mg} .100 \mathrm{~mL}^{-1}\right)$ and hesperitin (14.24 mg.100 mL $\mathrm{m}^{-1}$, when compared to the freshly squeezed orange juice, with $13.89 \mathrm{mg} .100 \mathrm{~mL}^{-1}$ total flavanones, $3.72 \mathrm{mg} .100$ $\mathrm{mL}^{-1}$ narigenin and $10.18 \mathrm{mg} .100 \mathrm{~mL}^{-1}$ hesperitin. Using different HHP conditions $\left(350 \mathrm{MPa}, 30^{\circ} \mathrm{C}\right.$ and $2.5 \mathrm{~min}$ and $400 \mathrm{MPa}, 40^{\circ} \mathrm{C}$ and $1 \mathrm{~min}$ ) for orange juice, Sánchez-Moreno $\mathrm{C}$ reported an increase in hesperitin content but no change was found for narigenin content.

Cao [37] studied the total phenolic content of strawberry pulps submitted to HHP. At $400 \mathrm{MPa}$ there was a decrease in total phenolic content regardless time of HHP treatment. The results were associated with the high residual activity of polyphenol oxidase and peroxidase, which are responsible to catalyze the oxidation of phenols [38]. At 500 and $600 \mathrm{MPa}$ the strawberry pulps had an increase in total phenolic content, related to the higher extractability of some antioxidant compounds.

The statistical analysis indicated that the quadratic model for total phenolic compounds was not significantly fit to the experimental data, as indicated by the regression model $F$ value of $1.87(\mathrm{p}<0.01)$, and did not present a satisfactory determination coefficient $\left(\mathrm{R}^{2}=0.51\right)$ (Table 3). These statistical parameters confirm the model does not have consistency, indicating it is not reliable to predict total phenolic compounds content in HHP treated orange juice.

\section{Effect of HHP treatment conditions on antioxidant activity}

Antioxidant activity of orange juice was determined using the $\mathrm{DPPH}^{\cdot}$ and $\mathrm{ABTS}^{\cdot+}$ assay. The antioxidant activity of non-treated orange juice was $2211.7 \mu \mathrm{mol}$ Trolox $\mathrm{L}^{-1}$ with $\mathrm{DPPH}^{\cdot}$ and 3176.7 $\mu$ mol Trolox $\mathrm{L}^{-1}$ with $\mathrm{ABTS}^{++}$, which are slight higher than the values reported by Miller NJ [39] $\left(2469 \mu \mathrm{mol}_{\text {Trolox L }}^{-1}\right)$ and Stella SP $(57.78$ to $349.32 \mu \mathrm{mol}$ Trolox $100 \mathrm{~mL}^{-1}$ ). The antioxidant activity of the HHP treated orange juice for each experimental condition is in Table 2. HHP treatment reduced antioxidant activity in orange juice, which ranged from 1745.3 to $2182.0 \mu \mathrm{mol}$ Trolox $\mathrm{L}^{-1}$ for $\mathrm{DPPH}^{\cdot}$ assay and from 2062.0 to $2935.9 \mu \mathrm{mol}$ Trolox $\mathrm{L}^{-1}$ for $\mathrm{ABTS}^{-+}$assay. The highest antioxidant activity of HHP orange juice using the $\mathrm{DPPH}^{\cdot}$ radical reaction was $2182.0 \mu \mathrm{mol}$ Trolox $\mathrm{L}^{-1}$, at $499 \mathrm{MPa}, 36^{\circ} \mathrm{C}, 97 \mathrm{~s}$ and for the $\mathrm{ABTS}^{*+}$ radical reaction, $2935.9 \mu \mathrm{mol}$ Trolox $\mathrm{L}^{-1}$, at $350 \mathrm{MPa}, 45^{\circ} \mathrm{C}, 30$ $\mathrm{s}$. The effect of HHP on antioxidant activity is not the same among food products, as it might influence vitamin stability and extraction yield of some bioactive compounds [40]. Indrawati O reported that HHP treatment increased antioxidant activity of carrot juice, but reduced that for orange juice (var Navelinas). According to Table 2 and Figure 2 , it is possible to observe that the lower the time and temperature of
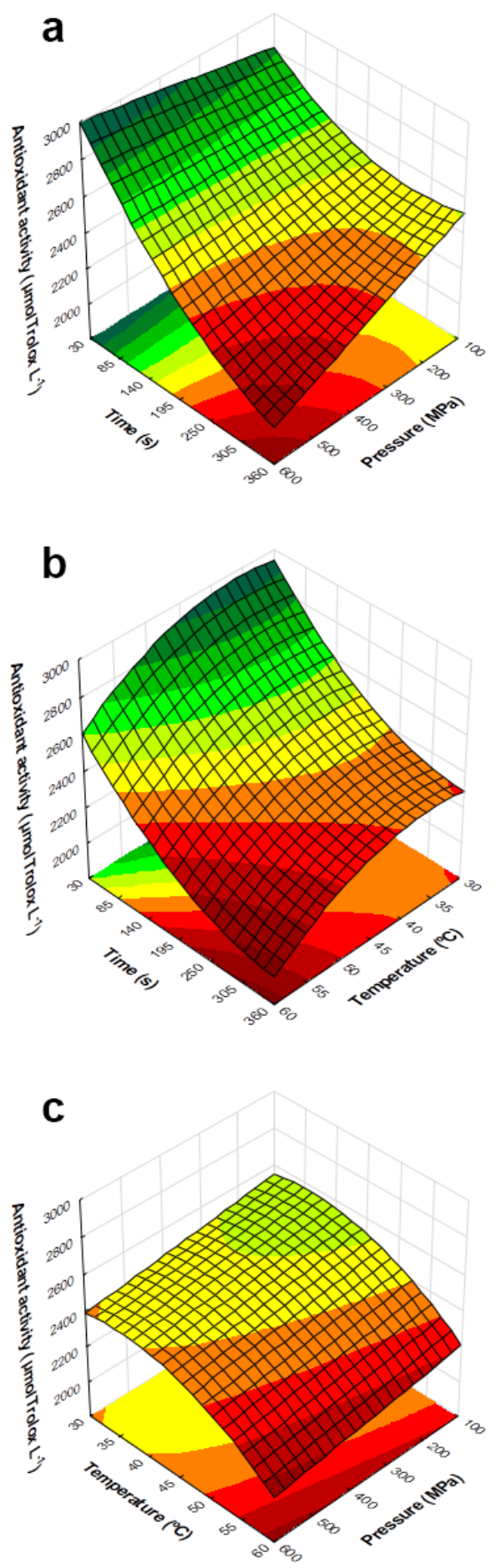

Figure 2: Response surface of the combined effects of time and pressure (a), time and temperature (b), and temperature and pressure (c) on the antioxidant activity of HHP processed orange juice.

HHP treatment the higher the antioxidant activity for $\mathrm{ABTS}^{\cdot+}$ assay.

The statistical analysis (Table 3 ) indicated that the quadratic model for antioxidant activity with $\mathrm{DPPH} \cdot$ assay was not significantly fit to the experimental data, as indicated by the regression model $F$ value of 1.08 , and did not present a satisfactory determination coefficient 
Citation: Bisconsin-Junior A, Alvarenga JFR, Rosenthal A, Monteiro M (2015) Effect of High Hydrostatic Pressure on Ascorbic Acid, Phenolic Compounds and Antioxidant Activity of Pera Rio Orange Juice. J Food Process Technol 6: 416. doi:10.4172/2157-7110.1000416

Page 6 of 7

$\left(\mathrm{R}^{2}=0.45\right)$. These statistical parameters confirm the model do not have consistency, indicating it is not reliable to predict antioxidant activity using the DPPH• assay of HHP treated orange juice.

On the other hand, the ANOVA (Table 3) demonstrated that the quadratic model for antioxidant activity using the $\mathrm{ABTS}^{+}$assay significantly fit the experimental data, as indicated by the regression model $F$ value of $7.20(\mathrm{p}<0.01)$, with determination coefficient $\left(\mathrm{R}^{2}\right)$ of 0.91 . The model presented no significant $(p>0.05)$ lack of fit. The linear terms of pressure $(P)$, temperature $(T)$ and time $(t)$, as well as the quadratic terms of temperature $\left(T^{2}\right)$ and time $\left(t^{2}\right)$, and the interaction term of pressure and time $(P t)$ were significant $(\mathrm{p}<0.1)$. These parameters confirm the reliability of the prediction model for antioxidant activity of HHP orange juice for the ABTS*+ assay. Using the significant regression coefficients (Table 4) the following equation for antioxidant activity using $\mathrm{ABTS}^{++}$assay was developed: (Equation 3 )

Antioxidant Activity $\left(\mathrm{ABTS}^{\cdot+}\right)=2127.168+0.498 \mathrm{P}+43.555 \mathrm{~T}-$ $2.662 \mathrm{t}-0.608 \mathrm{~T}^{2}+\left(5.518 \times 10^{-3}\right) \mathrm{t}^{2}-\left(4.180 \times 10^{-3}\right) \mathrm{Pt}$

where, Antioxidant Activity $\left(\mathrm{ABTS}^{*}\right)=$ antioxidant activity $(\mu \mathrm{mol}$ Trolox $\left.\mathrm{L}^{-1}\right), \mathrm{P}=$ pressure $(\mathrm{MPa}), \mathrm{T}=$ temperature $\left({ }^{\circ} \mathrm{C}\right)$ and $\mathrm{t}=$ time $(\mathrm{s})$.

Using the regression equation (Eq. 3) the response surface was generated to illustrate the effects of the independent variables on the antioxidant activity using $\mathrm{ABTS}^{*}$ assay (Figure 2). As observed for ascorbic acid content (Figure 1), the increase in temperature and time of HHP orange juice treatment promoted reduction in antioxidant activity (Figure 2). According to Figure 2a, when time was lower than $105 \mathrm{~s}$ the increase in pressure enhanced antioxidant activity, but when time was higher than $195 \mathrm{~s}$, pressure was inversely associated to antioxidant activity. Figure $2 \mathrm{c}$ shows that the increase in pressure resulted in slight reduction of antioxidant activity. Time was the most important variable affecting the reduction of antioxidant activity of HHP treated orange juice using $\mathrm{ABTS}^{++}$assay (Figure $2 \mathrm{a}$ and $2 \mathrm{~b}$ ). Orange juice antioxidant activity higher than $2550 \mu \mathrm{mol}$ Trolox L $\mathrm{L}^{-1}$, representing ca $80 \%$ of the initial orange juice antioxidant activity, can be obtained within the range of $100-320 \mathrm{MPa}, 30-42^{\circ} \mathrm{C}$ and $30-180 \mathrm{~s}$ HHP treatment conditions.

Antioxidant activity is related to the bioactive compounds present in food. It is well known that orange juice intake increases vitamin $\mathrm{C}$ in plasma, which provided antioxidant related health benefits. The ascorbic acid content and antioxidant activity using ABTS $^{*+}$ assay of HHP treated orange juice showed a positive and strong correlation $(\mathrm{R}=0.82)$. Ascorbic acid (Figure 1) and antioxidant activity (Figure 2) showed similar response concerning to the HHP temperature, pressure and time, indicating that the decrease in antioxidant activity could be attributed to the ascorbic acid degradation. These results are in agreement with those reported by Miller NJ, Sánchez-Moreno C and Stella SP, which showed that ascorbic acid is the main antioxidant compound in orange juice.

\section{Conclusion}

HHP treatment reduced the ascorbic acid content and antioxidant activity of orange juice. Time, temperature and pressure influenced the response variables. Time of HHP treatment showed the strongest influence on the reduction of ascorbic acid and antioxidant activity. The HHP treatment conditions of 100 to $250 \mathrm{MPa}, 30$ to $40^{\circ} \mathrm{C}$ and 30 to $125 \mathrm{~s}$ were able to produce orange juice with more than $70 \%$ of the initial ascorbic acid content and $80 \%$ of the antioxidant activity. The $\mathrm{ABTS}^{*+}$ assay fit well the antioxidant activity of orange juice. The effects of HHP treatment conditions on ascorbic acid and antioxidant activity of orange juice allowed establishing the most favorable range of process conditions in order to obtain high nutritional quality of orange juice.

\section{Acknowledgement}

The authors would like to thank FAPESP (São Paulo Research Foundation) $\left(n^{\circ}\right.$ 2011/11574-2) and PADC/FCF/UNESP for the financial support, and JBT FoodTech, Araraquara, SP, Brazil, for supplying the orange juice.

\section{References}

1. CitrusBR Associação Nacional dos Exportadores de Sucos de Cítricos.

2. Sánchez-Moreno C, Plaza L, Ancos B, Cano MP (2003) Quantitative bioactive compounds assessment and their relative contribution to the antioxidant capacity of commercial orange juices. Journal of Science of Food and Agriculture 83: 430-439.

3. Majo DD, Giammanco M, Guardia M, Tripoli E, Giammanco S, et al. (2005) Flavanones in Citrus fruit: Structure-antioxidant activity relationships. Food Research International 38: 1161-1166.

4. Peterson JJ, Dwyer JT, Beecher GR, Bhagwat SA, Gebhardt SE, et al. (2006) Flavanones in oranges, tangerines (mandarins), tangors, and tangelos: a compilation and review of the data from the analytical literature. Journal of Food Composition and Analysis 19: S66-S73.

5. Oliveira DM, Dourado GKZS, Cesar TB (2013) Hesperidin associated with continuous and interval swimming improved biochemical and oxidative biomakers in rats. Journal of the International Society of Sports Nutrition 10: $1-7$.

6. Gama JJT, Sylos CM (2005) Major carotenoid composition of Brazilian Valencia orange juice: Identification and quantification by HPLC. Food Research International 38: 899-903.

7. Krinsky NI, Johnson EJ (2005) Carotenoid actions and their relation to health and disease. Molecular Aspects of Medicine 26: 459-516.

8. Borradaile NM, Dreu LE, Barret PHR, Huff MW (2002) Inhibition of hepatocyte apoB secretion by naringenin: enhanced rapid intracellular degradation independent of reduced microsomal cholesteryl esters. Journal Lipid Research 43: $1544-1554$.

9. Cesar TB, Aptekmann NP, Araujo MP, Vinagre CC, Maranhão RC (2010) Orange juice decreases low-density lipoprotein cholesterol in hypercholesterolemic subjects and improves lipid transfer to high-density lipoprotein in normal and hypercholesterolemic subjects. Nutrition Research 30: 689-694.

10. Apterkmann NP, Cesar, TB (2013) Long-term orange juice consumption is associated with low LDL-cholesterol and apolipoprotein B in normal and moderately hypercholesterolemic subjects. Lipids in Health and Disease 12 119.

11. Simon JA (1992) Vitamin C and cardiovascular disease: a review. The journal of the American College of Nutrition 11: 107-25.

12. Ness AR, Khaw KT, Bingham S, Day NE (1996) Vitamin C status and serum lipids. European Journal of Clinical Nutrition 50: 724-729.

13. Sánchez-Moreno C, Cano MP, Ancos B, Plaza L, Olmedilla B, et al. (2003) Effect of orange juice intake on vitamin $C$ concentrations and biomarkers of antioxidant status in humans. American Journal of Clinical Nutrition: 78: 454460.

14. Hyoung SL, Coates GA (2003) Effect of thermal pasteurization on Valencia orange juice color and pigments. LWT Food Science and Technology 36: 153156.

15. Janzantti NS, Machado TV, Monteiro M (2011) Sensory acceptance of juice from FCOJ processing steps. Journal of Sensory Studies 26: 322-330.

16. Timmermans RAH, Mastwijk HC, Knol JJ, Quataert MCJ, Vervoort L, et al. (2011) Comparing equivalent thermal, high pressure and pulsed electric field processes for mild pasteurization of orange juice. Part I: Impact on overall quality attributes. Innovative Food Science \& Emerging Technology 12: 235243.

17. Vervoort L, Van Der Plancken I, Grauwet T, Timmermans RAH, Mastwijk HC et al. (2011) Comparing equivalent thermal, high pressure and pulsed electric field processes for mild pasteurization of orange juice Part II: Impact on specific chemical and biochemical quality parameters. Innovative Food Science \& Emerging Technology 12: 466-477. 
Citation: Bisconsin-Junior A, Alvarenga JFR, Rosenthal A, Monteiro M (2015) Effect of High Hydrostatic Pressure on Ascorbic Acid, Phenolic Compounds and Antioxidant Activity of Pera Rio Orange Juice. J Food Process Technol 6: 416. doi:10.4172/2157-7110.1000416

18. Deliza R, Rosenthal A, Abadio FBD, Silva CHO, Castillo C (2005) Application of high pressure technology in the fruit juice processing: benefits perceived by consumers. Journal of Food Engineering 67: 241-246.

19. Katsaros GI, Tsevdou M, Panagiotou T, Taoukis PS (2010) Kinetic study of high pressure microbial and enzyme inactivation and selection of pasteurization conditions for Valencia orange juice. International Journal of Food Science and Technology 45: 1119-1129.

20. Bisconsin-Junior A, Rosenthal A, Monteiro M (2014) Optimisation of hight hydrostatic pressure processing of Pêra Rio orange juice. Food Bioprocess Technology 7: 1670-1677.

21. Irwe S, Olsson I (1994) Reduction of pectinesterase activity in orange juice by high pressure treatment, in Minimal Processing of Foods and Process Optimization: An Interface, CRC Press, Boca Raton.

22. Parish ME (1998) High pressure inactivation of Saccharomyces cerevisiae endogenous microflora and pectinmethylesterase in orange juice. Journal of Food Safety 18: 57-65.

23. Bull MK, Zerdin K, Howe E, Goicoechea D, Paramanandhan P, et al. (2004) The effect of high pressure processing on the microbial, physical and chemical properties of Valencia and Navel orange juice. Innovative Food Science \& Emerging Technology 5: 135-149.

24. Ancos B, Sgroppo S, Plaza L, Cano MP (2002) Possible nutritional and healthrelated value promotion in orange juice preserved by high-pressure treatment. Journal of Science of Food and Agriculture 82: 790-796.

25. Sánchez-Moreno C, Plaza L, Ancos B, Cano MP (2003b) Vitamin C, provitamin A carotenoids, and other carotenoids in high-pressurized orange juice during refrigerated storage. Journal of Agricultural and Food Chemistry 51: 647-653.

26. Indrawati O, Van Loey A, Hendrickx M (2004) Pressure and temperature stability of water-soluble antioxidants in orange and carrot juice: a kinetic study. European Food Research and Technology 219: 161-166.

27. Sánchez-Moreno C, Plaza L, Elez-Martinéz P, Ancos B, Martín-Belloso, et al. (2005) Impact of high pressure and pulsed electric fields on bioactive compounds and antioxidant activity of orange juice in comparison with traditional thermal processing. Journal of Agricultural and Food Chemistry 53 4403-4409.

28. Plaza L, Sánchez-Moreno C, Elez-Martinéz P, Ancos B, Martín-Belloso, O et al. (2006) Effect of refrigerated storage on vitamin $C$ and antioxidant activity of orange juice processed by high-pressure or pulsed electric fields with regard to low pasteurization. European Food Research Technology 223: 487-493.
29. AOAC (2011) Official methods of analysis, Association of Official Analytical Chemists. Washington. USA.

30. Rodrigues MI, lemma AF (2009) Planejamento de experimentos e otimização de processos. Campinas: Cárita.

31. Stella SP, Ferrarezi AC, Santos KO, Monteiro M (2011) Antioxidant activity of commercial ready-to-drink orange juice and nectar. Journal of Food Science 76: C392-C397.

32. Asami DK, Hong YJ, Barrett DM, Mitchell AE (2003) Comparison of the total phenolic and ascorbic acid content of freeze-dried and air-dried marionberry, strawberry, and corn grown using conventional, organic, and sustainable agricultural practices. Journal of Agricultural and Food Chemistry 51: 12371241.

33. Rufino MSM, Alves RE, Brito ES, Pérez-Jiménez J, Saura-Calixto F et al. (2010) Bioactive compounds and antioxidant capacities of 18 non-traditional tropical fruits from Brazil. Food Chemitry 121: 996-1002.

34. Brasil (2000) Ministério da Agricultura Pecuária e do Abastecimento. Instrução Normativa No 1. de 07 de janeiro de 2000. Aprova o Regulamento Técnico Geral para fixação dos Padrões de Identidade e Qualidade para Polpa de Fruta. Brasília, Brazil.

35. Meléndez-Martínez AJ, Vicario IM, Heredia FJ (2007) Provitamin A carotenoids and ascorbic acid contents of the different types of orange juices marketed in Spain. Food Chemistry 101: 177-184.

36. Davey MW, Van Montagu M, Inzé D, Sanmartin M, Kanellis A, et al. (2000) Plant L-ascorbic acid: chemistry, function, metabolism, bioavailability and effects of processing. Journal of Science of Food and Agriculture 80: 825-860.

37. Cao X, Zhang Y, Zhang F, Wang Y, Yi J, et al. (2011) Effects of hight hydrostatic pressure on enzyme, phenolic compunds, anthocyanins, polymeric color and color of strawberry pulps. Journal of Science of Food and Agriculture 91: 877885 .

38. Queiroz C, Moreira CFF, Lavinas FC, Lopes MLM, Fialho E et al. (2010) Effect of high hydrostatic pressure on phenolic compounds, ascorbic acid and antioxidant activity in cashew apple juice. High Pressure Research 30: 5075013.

39. Miller NJ, Rice-Evans CA (1997). The relative contributions of ascorbic acid and phenolic antioxidants to the total antioxidant activity of orange and apple fruit juices and blackcurrant drink. Food Chemistry 60: 331-337.

40. Indrawati O, Van der Plancken I, Van Loey A, Hendrickx M (2008) Does high pressure processing influence nutritional aspects of plant based food systems? Trends in Food Science and Technology 19: 300-308. 